\title{
FDI and Indian Retail Sector: An Analysis
}

\author{
Dr. Namita Rajput, Associate Professor \\ Department of Commerce \\ Sri Aurobindo College, Malviya Nagar, Delhi-110017 \\ University of Delhi, India \\ Tel: 91-93-1218-0054,91-82-8588-8860Ｅ-mail: namitarajput27@gmail.com \\ Dr. Subodh Kesharwani \\ Assistance Professor (Senior grade) \\ School of Management Studies \\ Ground Floor, Academic Block-C, Room No. 18, Delhi-68, IGNOU, India \\ Tel: 91-93-5002-6685Ｅ-mail: subodhkesharwani@gmail.com
}

\author{
Akanksha Khanna (Corresponding author) \\ Research Scholar \\ IGNOU, Delhi, India \\ Tel: 91-97-8038-9975Ｅ-mail: akanksha.kh@gmail.com
}

\begin{abstract}
Received: May 22, 2012
Accepted: June 4, 2012

Online Published: June 28, 2012

doi:10.5430/jbar.v1n1p53

URL: http://dx.doi.org/10.5430/jbar.v1n1p53
\end{abstract}

\begin{abstract}
In the post-liberalisation period, changes in the consumer purchase behaviour are seen with growing liberalisation, rise in per capita income, GDP and explosion of brands. This rise in large base of consumers has been an attraction for big global retailers and major domestic corporate sector to invest in modern retail sector in India. This unprecedented rise in multiple brands has given Indian consumers a wider choice of products and ample opportunities to take advantage of in the present scenario. The retail industry is expected to grow at a rate of $14 \%$ by 2013. The first step towards allowing Foreign Direct Investment in Retail was taken in the year 2006. Subsequently the government of India has allowed 100\% FDI in single brand retail to give consumers greater access to foreign brands, with the ongoing debate whether it should be allowed in multi-brand retail or not. With emergence of new ways like E-retailing, Indian retail sector is growing at a faster rate along with the employment potential. The retail landscape is showing a marked change, along with changes in the strategies of retailers towards the suppliers so as to get the best advantage. With the rapidly changing retail scene, India is soon going to be one of the fastest growing regions having great potential. The objective of the present paper is to analyse the impact of the present retail FDI policy on Indian consumers and economy using SWOT analysis. The analysis reveals that it will have a positive impact on the growth of Indian economy as a whole.
\end{abstract}

Keywords: Foreign direct Investment, E-Retailing, Retailing, GDP, Multinationals, Policies, Infrastructure development

\section{Introduction}

Foreign Direct Investment, or FDI, is a measure of foreign ownership of domestic productive assets such as factories, land and organizations. Foreign direct investments have become the major economic driver of globalization, accounting for over half of all cross-border investments. It is cross border investment, where foreign assets are invested into the organizations of the domestic market excluding the investment in stock. It brings private funds from overseas into products or services. The domestic company in which foreign currency is invested is usually being 
controlled by the investing foreign company. Eg. An American company taking major stake in a company in India. Their ROI is based on the performance of the project.

Retail is the sale of goods to end users, not for resale, but for use and consumption by the purchaser. The retail transaction is at the end of the supply chain. Manufacturers sell large quantities of products to retailers, and retailers sell small quantities of those products to consumers. Thus, retailing is the last link that connects the individual consumer with the manufacturing and distribution chain. The retail industry in India is divided into organized and unorganized sectors accounting for Rs. 350 million of total revenues. Organized retailing refers to trading activities undertaken by licensed retailers, that is, those who are registered for sales tax, income tax, etc. These include the corporate- backed hypermarkets and retail chains, and also the privately owned large retail businesses. Indian retail is dominated by a large number of small retailers consisting of the local kirana shops, owner-manned general stores, chemists, footwear shops, apparel shops, paan and beedi (local betel leaf and tobacco) shops, hand-cart hawkers, pavement vendors, etc. which together make up the so-called "unorganized retail" or traditional retail. The last few years have witnessed the entry of a number of organized retailers opening stores in various modern formats in metros and other important cities. Unorganized retailers normally do not pay taxes and most of them are not even registered for sales tax, VAT, or income tax.

India, over the latter half of the previous decade, has been one of the most wanted and desired destinations for investors across the globe and is being considered as one of the world's most lucrative retailing destinations. It is of late often being hailed as one of the sunrise sectors in the economy. The retail sector in particular has received a constant buzz and excitement surrounding government policy to reframe and revisit the policy framework. India's retail sector is on its way of modernisation. Traditional markets are making way for new formats such as departmental stores, supermarkets and speciality stores. Westernised malls can be seen fast appearing in metros and tier-II cities, introducing the Indian consumer to an implausible shopping experience. There is an unprecedented growth in organized retailing business in recent years and is expected to grow further at a much faster rate. Major players like large industrial houses and MNCs have entered this area and they have expansion and collaboration plans with big Indian partners, owing to the nature of Indian retail market. There is a major division on the opinion on the impact of the growth of organized retail in the country. But there is no doubt on the role that FDI can play in supplementing domestic resources and in ensuring employment generation in the development of an economy. Nevertheless, still there is an elongated way to go before Foreign Direct Investment (FDI) in Indian Retail can be realised in its totality.

There are three different forms through which retail trade is carried out in India, namely:

\begin{tabular}{|l|l|l|}
\hline $\begin{array}{l}\text { Mono/Exclusive/Single Brand Retail } \\
\text { Shops }\end{array}$ & Multi-branded Retail Shops & Convergence Retail Outlets \\
\hline $\begin{array}{l}\text { Exclusive Showrooms either owned } \\
\text { or franchised out by the manufacturer. A } \\
\text { complete range of all the products } \\
\text { manufactured by the said manufacturer } \\
\text { under one brand name. }\end{array}$ & $\begin{array}{l}\text { In these kinds of stores, almost all } \\
\text { brands are available for a single } \\
\text { product type with this consumer } \\
\text { will have wide choice for the kind } \\
\text { of product he is willing to buy. }\end{array}$ & $\begin{array}{l}\text { These kinds of products have } \\
\text { almost all kinds of products, } \\
\text { required by a consumer, in } \\
\text { them. }\end{array}$ \\
\hline $\begin{array}{l}\text { The focus is on the brand name as now a } \\
\text { day's people buy images, not the } \\
\text { products. }\end{array}$ & $\begin{array}{l}\text { The focus is on the diverse nature } \\
\text { of product. }\end{array}$ & $\begin{array}{l}\text { The focus is on the diverse } \\
\text { nature of consumer needs. }\end{array}$ \\
\hline $\begin{array}{l}\text { e.g.: Exclusive showroom / franchise } \\
\text { outlets of Samsung, Nokia, Liberty, etc. }\end{array}$ & e.g.: Shoppers Stop, Croma, Max, & $\begin{array}{l}\text { e.g.: Big Bazaar, In \& Out, } \\
\text { Subhiksha, Grand India } \\
\text { Bazaar, etc. }\end{array}$ \\
\hline
\end{tabular}

The long awaited decisions of ease in FDI framework which was kept in cold storage was declared with this hope that FDI inflows will go up at an unprecedented levels. There was a global melt down of the world economy because of international factors. AT Kearney, the well-known international management consultancy firm, annually ranks emerging market economies based on more than 25 macroeconomic and retail-specific variables through their Global Retail Development Index (GRDI). In its 2011 edition, it has ranked India fourth indicating that the country is one of 
the most attractive markets for global retailers to enter. It has made India the cause of a good deal of excitement and the cynosure of many foreign eyes.

The 2012 A.T. Kearney FDI Confidence Index ${ }^{\circledR}$ examines future prospects for FDI flows as the world seeks to recover from the global recession and continued economic uncertainty in Europe and the United States. China, India, and Brazil occupy top three positions, and Southeast Asia, with its large and growing consumer base, makes a strong showing: Indonesia, Malaysia, Singapore, Thailand, and Vietnam all hold high rankings see figure (1) in Annexure.

These kind of global reports give lot of confidence in relation to India as a global destination as evidenced by the report, 2012 A.T. Kearney FDI Confidence Index. "Economic Survey 2010-11, tabled in Parliament on February 25, had this to say about the retail sector: "Permitting FDI (foreign direct investment) in retail in a phased manner beginning with metros and incentivizing the existing retail shops to modernize could help address the concerns of farmers and consumers. FDI in retail may also help bring in technical know-how to set up efficient supply chains which could act as models of development and easing of the retail ban would give a big boost to FDI flows into India, which have been declining the past couple of years". Retailers ought to take cognizance of the fact that both back-end and front-end operations require investment and hence, need to be developed in a manner appropriate with their overall business operations. Allowing the FDI in retail sector is lined with greater challenges, for both existing and potential market players alike. To meet the challenge retailers have to adapt to the new market realities, galvanize its supply chains, leverage the core competencies and tactically counter its competitors in a competitive way.

There is a huge untapped opportunity in the retail sector, thus having immense scope for new entrants, driving large investments into the country. A good talent pool, huge markets and availability of raw materials at comparatively cheaper costs are expected to make India lead one of the world's best retail economies by 2042 . The industry is also slated to be a major employment generator in future. The total retail sales in India will grow from US\$ 395.9 billion in 2011 to US\$ 785.1 billion by 2015, according to the BMI India Retail report for the third quarter of 2011

The objective of the present paper is to deeply analyse the recent FDI policy in retail sector of India i.e. to discuss its recent legal framework and provisions, forms, conditions, impact, strengths and weakness in view of changing dynamics of Indian retail landscape. The paper is divided into following sections; present section i.e. section I gives the basic insights of FDI in retail sector giving all the details about it relating to its conditions and forms and also about the changing image of India as a global destination. Section II gives brief review of literature followed by legal framework in Section III. Section IV gives the details of SWOT analysis of retail FDI in India .Followed by conclusion entailed in the next Section. Section VI gives the details of references used in the study.

\section{Review of Literature}

\subsection{Determinants of FDI Policies in India}

There are many studies which have identified technology, labour skills and infrastructure as the major determinants of foreign investment. These factors are very important to explain the patterns and trends in the geographical structure of FDI at the world capita income, in relation to outbound as well as inbound FDI ( Hummels and Stern, 1994). The incentives announced by the exchequer is also very important in formulating and analysing the corporate strategies of international location, also institutional, historical and cultural factors should be embedded in overall analysing and framing of policies, as these factors should not be ignored as they influence the investor's location related decisions (Martin and Velazquez, 1997). Whether tariff rate, exchange rate and tax rate are significant for FDI was tested in a study by Aqeel and Nishat (2004).In the study it was revealed that these policy variables were responsible for drawing FDI and it determined the growth in Pakistan and also showed the positive impact of reforms in Pakistan. On many variables affecting FDI have been examined, a set of descriptive variables were examined by several studies like (Chakraborty, 2001) and were found to be significant. Some studies have also analysed the variables like market size and differences in factor costs and were also found to be significant in determining the FDI location as these are very important in determining the market economies and they cannot be achieved and exploited till the time market achieves a certain size. (Markusen and Maskus, 1999). The most important measures used in many studies are GDP, GDP per capita and growth in GDP.

2.2 Research Studies Related to Changing Dynamics of Consumer Behaviour and Factors Affecting Retail Store Choice

There are many studies on Indian consumers, which reveal the shopping behaviour of Indian consumers. Various parameters are included in their studies like level of income, education, and international exposure (Ramachander 1988), gender and age (Sinha, et al. 2002) and distance from the store (Sinha 2003). As far as shopping behaviour of 
Indian consumers across different retail outlets, traditional outlets are preferred mainly because we have a large chunk of middle class consumers who are very good bargainers while modern outlets are preferred because they link entertainment with shopping and now-a-days it's a customer delight to go out for shopping and entertainment together (Sinha 2003).There are number of studies which are done taking many parameters which affect the choice of retail store these are product quality, goodwill ,lower prices, better shopping experience, availability of product, play area ,parking facility, whereas on the other hand proximity to residence, easy availability of credit, ,convenient timings, possibility of bargain, etc are a few paybacks of traditional outlets as mentioned by a study done by Joseph and Soundararajan 2009. It is a complete myth that big retail outlets are high-priced; there is empirical evidence to this fact and they the level of savings depends on the type of retail format - it is more for discounters and supermarkets, and less for hypermarkets. The main advantage of this transition of modernisation of retail stores is the consumer as they get the best and wide choice, discounted prices and they are the focus point of strategies formulated by the strategist as regard their retention plans. All the policies are formulated keeping many factors into considerations like their likes and dislikes dynamics, their buying behaviour psychology, what factor motivate them to buy. Domestic players are selectively growing in India postponing aggressive expansion plans, adding stores judiciously and shifting gears to tier 2 and 3 cities. Aditya Birla Group plans to open about 100 supermarkets and 10 hypermarkets by mid-2011. Spencer's is expected to add up to 25 hypermarkets through 2012. Reliance Retail, India's organized retail leader, plans to open 150 Reliance Trends apparel and accessories stores in the next year.

Large Indian players like Reliance, Ambanis, K Rahejas, Bharti AirTel, ITC and many others are making significant investments in this sector leading to emergence of big retailers who can bargain with suppliers to reap economies of scale. Rise in retail modernize India and facilitate rapid economic growth. This would help in efficient delivery of goods and value-added services to the consumer making a higher contribution to the GDP.

The Indian Retail growth can be attributed to the several factors including

- Demography Dynamics: Approximately 60 per cent of Indian population below 30 years of age.

- Double Incomes: Increasing instances of Double Incomes in most families coupled with the rise in spending power.

- Plastic Revolution: Increasing use of credit cards for categories relating to Apparel, Consumer Durable Goods, Food and Grocery etc.

- Urbanisation: increased urbanisation has led to higher customer density areas thus enabling retailers to use lesser number of stores to target the same number of customers. Aggregation of demand that occurs due to urbanization helps a retailer in reaping the economies of scale.

- Covering distances has become easier: with increased automobile penetration and an overall improvement in the transportation infrastructure, covering distances has become easier than before. Now a customer can travel miles to reach a particular shop, if he or she sees value in shopping from a particular location.

Kaur and Singh (2007) revealed an interesting fact that was revealed that children are becoming key decision-makers in household purchases. There is a gap in these studies as they haven't corroborated on the implication of the existing policy on consumers.

\section{Policy Framework of Retail FDI in India}

India had to open retail sector being a signatory to World Trade Organisation's General Agreement on Trade in Services, which include wholesale and retailing services. There were many apprehensions towards opening of this sector .Various reasons were there for this like fear of job losses, procurement from international market, competition and loss of entrepreneurial opportunities. However, the government in a series of moves has opened up the retail sector slowly to foreign sector. In 1997, FDI in cash and carry (wholesale) with 100 percent ownership was allowed under the Government approval route. It was brought under the automatic route in 2006. 51 percent investment in a single brand retail outlet was also permitted in 2006. FDI in Multi-Brand retailing is prohibited in India. The Government of India has reviewed the extant policy on FDI and decided that FDI, up to 100\%, under the government approval route, would be permitted in Single-Brand Product. Accordingly, the following amendment is made in 'Circular 1 of 2012- Consolidated FDI Policy', dated 10.04.2012, issued by the Department of Industrial Policy \& Promotion (DIPP) http://dipp.nic.in:

\subsection{Single Brand product retail trading}

(1) Foreign Investment in Single Brand product retail trading is aimed at attracting investments in production and marketing, improving the availability of such goods for the consumer, encouraging increased sourcing of goods from 
India, and enhancing competitiveness of Indian enterprises through access to global designs, technologies and management practices.

(2) FDI in Single Brand product retail trading would be subject to the following conditions:

(a) Products to be sold should be of a 'Single Brand' only.

(b) Products should be sold under the same brand internationally i.e. products should be sold under the same brand in one or more countries other than India.

(c) 'Single Brand' product-retail trading would cover only products which are branded during manufacturing.

(d) The foreign investor should be the owner of the brand.

(e) In respect of proposals involving FDI beyond 51\%, mandatory sourcing of at least $30 \%$ of the value of products sold would have to be done from Indian 'small industries/ village and cottage industries, artisans and craftsmen'. 'Small industries' would be defined as Retail Trading, subject to specified conditions, as industries which have a total investment in plant \& machinery not exceeding US \$ 1.00 million. This valuation refers to the value at the time of installation, without providing for depreciation. Further, if at any point in time, this valuation is exceeded, the industry shall not qualify as a 'small industry' for this purpose. The compliance of this condition will be ensured through self-certification by the company, to be subsequently checked, by statutory auditors, from the duly certified accounts, which the company will be required to maintain.

(3) Application seeking permission of the Government for FDI in retail trade of 'Single Brand' products would be made to the Secretariat for Industrial Assistance (SIA) in the Department of Industrial Policy \& Promotion. The application would specifically indicate the product/ product categories which are proposed to be sold under a 'Single Brand'. Any addition to the product/ product categories to be sold under 'Single Brand' would require a fresh approval of the Government.

(4) Applications would be processed in the Department of Industrial Policy \& Promotion, to determine whether the products proposed to be sold satisfy the notified guidelines, before being considered by the Foreign Investment Promotion Board (FIPB) for Government approval.

Retailers in India

\begin{tabular}{|l|l|}
\hline \multicolumn{1}{|c|}{ Retailer } & \multicolumn{1}{|c|}{ Stores } \\
\hline Pantaloon Retail & $\begin{array}{l}\text { Big bazaar, Food bazaar , Hometown, furniture bazaar, } \\
\text { collection-I,e-zone, } \\
\text { shoefactory,Depot,Futurbazaar.com,Bowling co. }\end{array}$ \\
\hline K Raheja Group & Shopper's Stop, Crossword, Homes stop, Mothercare. \\
\hline Tata Group & Westside, Star India Bazaar, Croma, Titan, Tanishq. \\
\hline RPG Group & Foodworld, Spencer's, Music World \\
\hline Landmark & $\begin{array}{l}\text { Lifestyle, Home Centre, Landmark International, Max Retail, } \\
\text { Funcity. }\end{array}$ \\
\hline Piramal Group & TruMart, Priamyd Megastore \\
\hline Reliance & Reliance Hyper-mart \\
\hline Aditya Birla Group & $\begin{array}{l}\text { Louis Phillipe, Van Heusen, Allen Solly, Peter England, } \\
\text { Trouser town }\end{array}$ \\
\hline
\end{tabular}

\subsection{Present entrance routes for the Foreign Investors}

In view of the restrictive entrance policies for the foreign investors in the retail sector, they followed one or more of the following routes to expand their business in India: 


\begin{tabular}{|c|c|c|c|}
\hline $\begin{array}{c}\text { A. Franchise } \\
\text { Agreement }\end{array}$ & $\begin{array}{c}\text { B. Cash and Carry } \\
\text { Wholesale Agreement }\end{array}$ & $\begin{array}{c}\text { C. Strategic Licensing } \\
\text { Agreement }\end{array}$ & $\begin{array}{c}\text { D. Manufacturing and } \\
\text { Wholly-owned } \\
\text { Subsidiary }\end{array}$ \\
\hline $\begin{array}{l}\text { It is an easiest track to } \\
\text { come in the Indian } \\
\text { market. In franchising } \\
\text { and commission agents' } \\
\text { services, FDI (unless } \\
\text { otherwise prohibited) is } \\
\text { allowed with the } \\
\text { approval of the Reserve } \\
\text { Bank of India (RBI) } \\
\text { under the Foreign } \\
\text { Exchange Management } \\
\text { Act. This is a most usual } \\
\text { mode for entrance of } \\
\text { quick food bondage } \\
\text { opposite a world. Apart } \\
\text { from quick food bondage } \\
\text { identical to Pizza Hut, } \\
\text { players such as Lacoste, } \\
\text { Mango, Nike as good as } \\
\text { Marks as good as } \\
\text { Spencer, have entered } \\
\text { Indian marketplace by } \\
\text { this route. }\end{array}$ & $\begin{array}{l}100 \% \text { FDI is allowed in } \\
\text { wholesale trading which } \\
\text { involves Building of a } \\
\text { large } \\
\text { infrastructure to astribution } \\
\text { local manufacturers. The } \\
\text { wholesaler deals only with } \\
\text { Smaller retailers and not } \\
\text { Consumers. Metro AG of } \\
\text { Germany was the first } \\
\text { significant global player to } \\
\text { enter India through this } \\
\text { route. }\end{array}$ & $\begin{array}{l}\text { Some foreign brands give } \\
\text { exclusive licences and } \\
\text { distribution Rights to } \\
\text { Indian companies. } \\
\text { Through these rights, } \\
\text { Indian companies can } \\
\text { either sell it through their } \\
\text { own Stores, or enter into } \\
\text { shop-in-shop arrangements } \\
\text { or distribute the brands to } \\
\text { franchisees. Mango, the } \\
\text { Spanish apparel brand has } \\
\text { entered India through this } \\
\text { route with an agreement } \\
\text { with Piramyd, Mumbai, } \\
\text { SPAR entered into a } \\
\text { similar agreement with } \\
\text { Radhakrishna Foodlands } \\
\text { Pvt. Ltd }\end{array}$ & $\begin{array}{l}\text { The foreign brands such } \\
\text { as Nike, Reebok, } \\
\text { Adidas, etc. that have } \\
\text { wholly-owned } \\
\text { subsidiaries } \\
\text { manufacturing an } \\
\text { treated as Indian } \\
\text { companies and are, } \\
\text { Therefore, allowed to do } \\
\text { retail. These companies } \\
\text { have been authorised to } \\
\text { sell products to Indian } \\
\text { consumers } \\
\text { By franchising, internal } \\
\text { distributors, existent } \\
\text { Indian retailers, own } \\
\text { outlets, etc. For instance, } \\
\text { Nike entered through an } \\
\text { exclusive licensing } \\
\text { agreement with Sierra } \\
\text { Enterprises but now has } \\
\text { a wholly owned } \\
\text { subsidiary, Nike India } \\
\text { Private Limited. }\end{array}$ \\
\hline
\end{tabular}

\subsection{Present Position of FDI in India}

The table 1 in annexure shows total amount of FDI inflows from April 2000 to January 2012 to 204.07 crores/44.45 US Dollars, with a $\%$ of 0.03 with respect to total FDI inflows. The Indian government is very much aware that people of India are becoming brand-conscious, there is a large market, growing consumerism, and increasing disposable income. All these factors can give a big push to this sector and can help in achieving sustainable high economic growth. It also wants to develop India as an outsourcing hub for foreign retailers. Supporters of FDI in retail have argued that it will lead to better supply chain management and reduce inflation in the economy.

\subsection{Challenges and Opportunities of FDI in Retail Sector}

There are linkages and relation between important parameters like between economic development, rise in per capita income, growing consumerism, proliferation of branded products, and retail modernisation. With high economic growth, there is rise in per capita income which in turn changes the consumption pattern. With the persistence of globalisation and liberalisation various international brands enter the domestic market. There is amplification of awareness level of Consumers as they lean to experiment with different international brands. The proliferation of brands leads to increase in retail space. Thus, retail modernisation is an essential part of the development process. Despite the present FDI restrictions, a number of studies such as A.T. Kearney (2011), McKinsey \& Company (2007) and A C Nielsen (2008) predict that modern retail will continue to witness double-digit growth in India. The Indian market is unsaturated and A.T. Kearney 2011 has pointed out that it is the right time for global retailers to enter the Indian market.

\section{SWOT Analysis of Open FDI Policy}

In any strategic planning process, two factors namely internal and external Environmental factors play an important role. A thorough scan of these factors is important for further planning. The environmental factors, which are internal to the retail sector, can be classified as strengths and weakness. The factors, which are external to the sector, can be classified as opportunities and threats. The strategic analysis of environmental factors is referred as SWOT analysis. This analysis provides the information that is helpful in understanding the retail sector resource mobilization and capabilities to the competitive environment in which it operates. Finally, this will be an instrumental in formulation of strategies for future growth and development of the sector. 


\subsection{Strengths}

B Boost up competition: Welcoming the FDI in retail industry can prove advantageous for India as it increase the competition in retail chain at domestic level. The competition always demands the innovation and differentiation and the out result of these two is the quality goods. As the competition increases, the competitor is compelled to serve quality of goods at competitive at reasonable price.

$>$ Benefits to farmers: In most cases, in the retailing business, the intermediaries have dominated the interface between the manufacturers or producers and the consumers. Hence the farmers and manufacturers lose their margins as the major share is eaten up by the middle men. This issue can be resolved by FDI, as farmers might get contract farming where they will supply to a retailer based upon demand and will get good cash for that, they need not to search for buyers.

$>$ Benefits to consumers: Consumer will get assortment of products at squat prices compared to market rates, and will have more options to get international brands at one place. because of competitive prices, and will improve the standard of living of the consumers

> Generate Employment opportunities: Bharti Walmart, a joint venture between Bharti Enterprises and Wal-Mart Stores, will open a training centre at Jalna in Maharashtra on a public private partnership basis, according to a press note released on April 27, 2012. Bharti Walmart currently runs three such training centres under the PPP model in Amritsar, Delhi and Bangalore, and three training centres at its modern wholesale stores in Zirakpur, Jalandhar and Ludhiana. The domestic retail sector is growing fast providing growth opportunities. However, the industry lacks the talent pool with required skill sets to leverage this huge potential. Bharti Walmart training centres aim to bridge this gap by imparting training in various aspects of retailing to under-privileged youth making them employable in the retail sector

$>$ Efficient Banking Services: Efficient and customized services of bank's today, is a result of effective competition which increases only after the foreign players were welcomed in arena

$>$ Large scale investments: It has also contributed to large scale investments in the real estate sector with major national and global players investing in devolving the infrastructure and construction of the retailing business.

$>$ Increased Purchasing power: Large domestic market with an increasing middle class and potential customers with purchasing power.

$>$ Ranked second in Global Retail Development Index of 30 developing countries drawn up by AT Kearney and hence considered as a potential sector.

$>$ The annual growth of departmental stores is estimated at $24 \%$ which will add to substantial surge in the country's overall economic development.

\subsection{Weaknesses}

$>$ Lack of 'Industry' status, thereby creating financial issues for retailers: The retail sector in India does not enjoy the status of an "Industry", thereby making difficult for the retailers to raise funds for the expansion projects as it is easier to access the flow of funds with that status.

$>$ Lack of Infrastructure: Lack of infrastructure in the retailing chain has been one of the major issues of concern which has led the process to an incompetent market mechanism. For example, in spite of India being one of the largest producers of vegetables and fruits, lack of proper count of cold storages has significantly affected the selling of these perishable items. FDI might help India overcome such issues by channelizing the resources in the right manner.

$>$ Catering to high end customers: This will mainly cater to high-end consumers placed in metros and will not deliver mass consumption goods for customers in villages and small towns.

$>$ Volume of sales is very low: The volume of sales in Indian retailing is low. India has largest population in the world and a fast growing economy.

$>$ Rising retail real estate rentals: The rapid development of retail sector is the sharp improvement in the availability of retail space. But the current surge in property prices, retail real estate rentals have escalated significantly, which may render a few retailing business houses unavailable. Retail companies have to pay high rentals which are block the profits. 
$>$ Small size outlets: Small size outlets are also one of the major weaknesses in the Indian retailing. More than $96 \%$ of the outlets are lesser than 500 sq.ft and are also smaller than those in the developed countries.

$>$ Inadequate merchandise mix: Retail chains are not settled down as on date with proper merchandise mix for the mall outlets. Retailing today is not about selling at the shop, but also about researching and surveying the market, offering choice, competitive prices and retailing consumers; hence there is a long road ahead.

\subsection{Opportunities}

$>$ Improvement in quality standards: The inflow of FDI in retail sector is bound to pull up the quality standards and cost-competitiveness of Indian producers in all the segments and hence India will significantly flourish in terms of Consumer Expectations.

> Improving Distribution and Warehousing Technologies: The technical know-how from global firms, such as warehousing technologies and distribution systems, will lend itself to improving the supply chain in India, especially for agricultural produce.

D Attractive Market: Global retail giants take India as key market .It is rated fifth most attractive retail market. Indian retail industry has come forth as one of the most dynamic and fast paced industry with several players entering the market. The organised retail sector is expected to grow stronger than GDP growth in the next five years driven by changing lifestyles, increase in income, purchasing power and favourable demographic outline. Food and apparel retailing are key drivers of growth.

$>$ There will be more organization in the sector. There are numerous empirical evidences across globe relating to massive increase in the employment opportunities as the sector grows after the reforms were initiated in countries like US and China. India is likely to experience the same situation in this liberalised and open regime of FDI in retail sector in India. It can become one of the largest industries in terms of numbers of employees and establishments. Once the concept picks up, due to demonstration effect, there will be an overall up-gradation of domestic retail trade.

$>$ Rural retailing is still unexploited Indian market and could act as an opportunity for the giants to venture into the retail market.

$>$ Promotes Healthy competition check on inflation: Retail giants such as Wal-Mart, Carrefour, Tesco, Target, Metro, Coop and 350 other global retail companies are already having operations in many countries for over 30 years. Contrary to a view prevailing across the globe that these MNCs will become a source of monopolies, rather they have managed to keep a check on the food inflation through their healthy competitive practices and giving variety and reasonably priced products to the customers.

$>$ More transparency compared to traditional Mandi systems: The intermediaries operating in the Indian system are not adhering to transparency in the system relating to their price strategies. According to some of the reports, an average Indian farmer realise only one-third of the price, which a final consumer pays, but there will be more rationality and transparency in the pricing policies of theses MNCs.

$>$ Eviction of Intermediaries and directly benefitting the farmers and producers at large: The prices of the commodities will be automatically checked. For example, according to the Business Standard, Walmart has introduced "Direct Farm Project" at Haider Nagar near Malerkotla in Punjab, where 110 farmers have been connected with Bharti Walmart for sourcing fresh vegetables directly. These strategies will benefit unswervingly the farmers and producers at large in respect of realisation of true prices evicting the intermediaries.

$>$ Quality Control and control over leakage and wastage: There are number of issues relating to malpractices and inefficiencies of the traditional system by which children are not able to get the proper food (malnourished), there are losses, food gets rotten in the transit etc. To correct this system and make available cheap product with good quality is an important step in their (MNC) endeavour, which is possible by open FDI as Cost-cautious and highly competitive retailers will try to avoid these wastage and looses and it will be their endeavour to make the products available at lowest prices, hence making food available to the weakest and poorest segment of Indian society which is the need of today.

$>$ Heavy flow of foreign capital will help in building up the infrastructure for the growing population: India is a capital deficit country with big challenges of growing population, developmental needs and with its present budgetary deficit cannot satisfy the growing needs (schools, hospitals, transport, and 
infrastructure) of the ever growing Indian Population. Hence foreign capital inflow will bridge this gap and will enable to create a heavy and good capital base.

$>$ Sustainable development and regulated system: There will be sustainable development and many other vital economic issues will be focused upon like child labour, overtime, not taking of their welfare. These issues will not have any room in this transparent open system as contract between the employer and worker will evict corruption from grass root level and will control black money.

\subsection{Threats}

$>$ Massive Job Losses: Indian economy is a developing economy and the level of development is not as desired. Due to paucity of infrastructure resources in Indian economy, there is a direct threat from big giants like Wal-Mart, which will compel current independent stores to close which will directly lead to massive job losses, as their level is very high, fully automated which need very few people to operate. This will lead to massive job losses; also since the Sector is unable to employ retail staff on contract basis, this becomes a biggest threat for the Indian economy.

$>$ Sustaining of loss strategy: Another challenge and threat Indian companies perceive is the sustaining of the loss by initially lowering the price to penetrate the market and this is a very usual policy adopted by these big players. They can afford to lower the prices in initial stages in order to knock-out the competition and become a monopoly and later on raise the prices like was done by Pepsi and Coke.

> Inequitable Competition: It would lead to very inequitable competition and eventually result in large-scale exit of domestic retailers, especially the small family managed outlets, leading to large scale displacement of persons employed in the retail sector. Further, as the manufacturing sector has not been growing fast enough, the persons displaced from the retail sector would not be absorbed there.

$>$ Repatriation of profits outside India: India doesn't need foreign retailers, since home grown companies and traditional markets may be able to do the job. Just like in BPO industry, work will be done by Indians, profits will go to foreigners hence is not viable solution for Indians. We cannot ever forget the example of East India Company. It entered India as a trader and then took over politically.

$>$ Persistence of Political inconclusiveness of issues: There is still no consensus made by government .In a politically and culturally diverse country like India, within no time every economic issues turns out to become a political issue and there is a persistence of inconclusiveness on the issue.

$>$ Offensive public opinion: There are strong apprehensive comments and action seen by the proliferation of these stores. A Wall Street Journal article reports that in Uttar Pradesh, Uma Bharti, a senior leader of the opposition Bharatiya Janata Party (BJP), threatened to "set fire to the first Wal-Mart store whenever it opens;" with her colleague Sushma Swaraj busy tweeting up a storm of misinformation about how Wal-Mart allegedly ruined the U.S. economy. With these offensive comments to develop a consensus is a most challenging job by government of India.

$>$ Immature, undersize and nascent stage of India retail sector: Another concern of Government of India is that the Indian retail sector, particularly organized retail, is still immature, undersized and is in a nascent stage and that, therefore, it is important that the domestic retail sector is allowed to nurture and strengthen first, before fully opening this sector to foreign investors.

$>$ Monopolistic tendencies and unnatural price trends: Another concern is that the global retailers would conspire and exercise monopolistic power to raise prices and monopolistic (big buying) power to reduce the prices received by the suppliers.

> Asymmetric growth of cities: It would lead to asymmetrical growth in cities, causing discontent and social tension elsewhere. Hence, both the consumers and the suppliers would lose, while the profit margins of such retail chains would go up.

$>$ Labour rules and regulation are also not followed in the organized retails.

$>$ Lack of uniform tax system for organized retailing is also one of the obstacles.

$>$ Inadequate infrastructure is likely to be an obstacle in the growth of organized retails.

\section{Conclusion}

In view of the above discussion, if we try to balance the opportunities and prospects attached to the given economic reforms, it could be advantageous for Indian economy once executed. The amendments made in 'Circular 1 of 2012- 
Consolidated FDI Policy', dated 10.04.2012, issued by the Department of Industrial Policy \& Promotion (DIPP) will have a positive impact on the retail industry and the country by attracting more foreign investments. With big retail giants coming to India, it will surely improve our back-end storage and procurement process. Once these multi-chain retailers establish themselves, they will create infrastructure facilities, which will also propel the existing infrastructure. This has been evident on January $11 \& 12$, 2012, when the notification increasing FDI limit in single-brand retail from $51 \%$ to $100 \%$, was announced. FDI in multi-brand retail' should also be given a green signal as soon as possible. Keeping in view the above benefits (or opportunities mentioned above), it is very reasonable to say that the period for which we delay these reforms will be a loss for the Government only, since majority of the public is in favour of this reform. The farmers will benefit from FDI as they will be able to get better prices for their produce. The elimination of the intermediate channels in the procurement process will lead to reduction of prices for consumers respectively.

The regulation in the FDI Bill that $30 \%$ of the total procurement has to come from small and medium enterprises will benefit the domestic businesses. Of course a policy is needed to protect the small and medium market channels from Chinese invasion. The whole economy will be benefitted including government and people at large with the reform process. Retailers venturing the Indian market must ensure that they have considered the opportunities and the challenges to maximize their returns. Retailers will need to bank on the local knowledge brought in by their partners, employees, service providers to reduce the lead time required by them to establish operations and get a firm place in the Indian market. There is a need for a symbiosis approach for the welfare of the public at large.

\section{References}

AC Nielsen. (2008). Consumer and Designer Brands. AC Nielsen, April 2008. [Online] Available: http://id.nielsen.com/news/documents/GlobalNielsenLuxuryBrandsMay08.pdf.Accessed 14th June 2011.

Aqeel, A. and Nishat, M. (2004). The Determinants of Foreign Direct Investment in Pakistan, PIDE-Journal Articles, Pakistan Institute of Development Economics, vol. 43, no. 4, pg 651-664.

A.T. Kearney. (2010). Expanding Opportunities for Global Retailers-2010 Global Retail Development Index, A.T.Kearney, $2010 . \quad$ [Online] Available: http://www.atkearney.com/images/global/pdf/2010_Global_Retail_Development_Index.pdf.

A.T. Kearney. (2011). Retail Global Expansion: A Portfolio of Opportunities-2011Global Retail DevelopmentIndex, A.T.Kearney, 2011 [Online] Available: http://www.atkearney.com/images/global/pdf/Retail_Global_Expansion-DI_2011.pdf.

Babu, H. S. (2012). SWOT analysis for opening of FDI in Indian Retailing, European Journal of Business and Management. ISSN 2222-1905 (Paper) ISSN 2222-2839 (Online).Vol 4, No.3, 2012.

CBRE. (2011). How Global is the Business of Retail. CB Richard Ellis, Global Research and Consulting, 2011 Edition. [Online]

Available:

http://www.atkearney.com/index.php/Publications/retail-global-expansion-a-portfolio-of-opportunities2011-globalret ail-development-index.html.

Chakrabarti, A. (2001). The Determinants of Foreign Direct Investment: Sensitivity Analyses of Cross-country Regressions, Kyklos, vol. 54, pg 89-114. http://dx.doi.org/10.1111/1467-6435.00142

Hemant Batra. (2010). Retailing Sector in India Pros Cons (Nov 30, 2010). http://dx.doi.org/10.1363/4308811

Hummels, D.L. and Stern, R. (1994). Evolving Patterns of North American Merchandise Trade and Foreign Direct Investment, $1960 \quad-\quad 1990$, The World Economy, January, pg 5-29. http://dx.doi.org/10.1111/j.1467-9701.1994.tb00806.x

Images. (2009). India Retail Report 2009, Images Group, 2009.

Joseph, M. and Nirupama Soundararajan. (2009). Retailing in India: A Critical Assessment, Academic Foundation, New Delhi.

Kaur, P. and Raghbir Singh. (2007). Uncovering Retail Shopping Motives of Indian Youth, Young Consumers: Insight and Ideas for Responsible Marketers, Vol. 8, No. 2, pp 128-138. http://dx.doi.org/10.1108/17473610710757491

Kinra, N. (2006). The Effect of Country-of-origin on Foreign Brand Names in the Indian market, Marketing Intelligence \& Planning, Vol. 24, No. 1, pp.15 - 30. http://dx.doi.org/10.1108/02634500610641534 
Markusen, J., and Maskus, K. (1999). Discriminating Among Alternative Theories of the Multinational Enterprises, NBER Working Paper, No. 7164.

McKinsey \& Company. (2007). The 'Bird of Gold': The Rise of India's Consumer Market, McKinsey Global Institute, 2007. [Online] Available: http://www.mckinsey.com/mgi/reports/pdfs/india_consumer_market/MGI_india_consumer_full_report.pdf.

Ministry of Food Processing Industries. (2011). Annual Report 2010-11, Ministry of Food Processing Industries (2011). [Online] Available: http://mofpi.nic.in/images/ar10-11.pdf.

Mukherjee, A. and Nitisha Patel. (2005). FDI in Retail Sector: India, Academic Foundation, New Delhi.

Pulkit Agarwal, Foreign Direct Investment in Indian Retail sector, [Online] Available: $\mathrm{http} / / / \mathrm{www}$. legalindia.in/foreign-direct-investment-in-indian-retail-sector-\%E2\%80\%93-an-analysis

Ramachander, S. (1988). Consumer Behaviour and Marketing: Towards an Indian Approach? Economic and Political Weekly, Vol. 23, No. 9 pp. M22-M2518.

Rao, S. L. (1998). Brand Building in Indian Industry, Economic and Political Weekly, Vol. 33, No. 40, pp. 2566-2568.

Rao, S. L. (2000). India's Rapidly Changing Consumer Markets, Economic and Political Weekly, Vol. 35, No. 40, pp. 3570-3572.

Shukla, R. (2010). How India Saves Earns Spends and Saves: Unmasking the Real India, SAGE Publications India Private Limited and NCAER.

Sinha, P. K., Arindam Banerjee, and Dwarika Prasad Uniyal. (2002). Deciding Where to Buy: Store Choice Behaviour of Indian Shoppers, Vikapa, Indian Institute of Management, Vol. 27, No. 2.

Sinha, P.K. (2003). Shopping Orientation in the Evolving Indian Market, Vikalpa, Vol. 28, No. 2, pp. 13-22, AprilJune 2003.

[Online] Available: http://dipp.gov.in/English/acts_rules/Press_Notes/pn1_2012.pdf

[Online] Available: http://www.economywatch.com/foreign-direct-investment/

[Online] Available: http://www.fibre2fashion.com/industry-article/7/604/fdi-in-retailing1.asp

[Online] Available: http://www.indiainbusiness.nic.in/industry-infrastructure/service-sectors/retailing3.htm

[Online] Available: http://retailindustry.about.com/od/glossary/g/retailterminolo.htm

Table 1. Statement on Sector-Wise FDI Inflows from April 2000 to January 2012

\begin{tabular}{|l|l|l|l|l|}
\hline SECTOR & $\begin{array}{l}\text { AMT OF FDI } \\
\text { INFLOWS(CRS, RS) }\end{array}$ & $\begin{array}{l}\text { AMT OF FDI } \\
\text { INFLOWS(US } \\
\text { DOLLAR) }\end{array}$ & $\begin{array}{l}\text { \%WITH TOTAL FDI } \\
\text { INFLOWS }(+)^{*}\end{array}$ \\
\hline $\begin{array}{l}\text { RETAIL TRADING } \\
\text { (SINGLE BRAND) }\end{array}$ & 204.07 & 44.45 & 0.03 & \\
\hline
\end{tabular}

*(i) '+"'Percentage of inflows worked out in terms of US\$ \& the above amount of inflows received through FIPB/SIA route, RBI's automatic route \& acquisition of existing shares only.

SOURCE: http://dipp.nic.in 


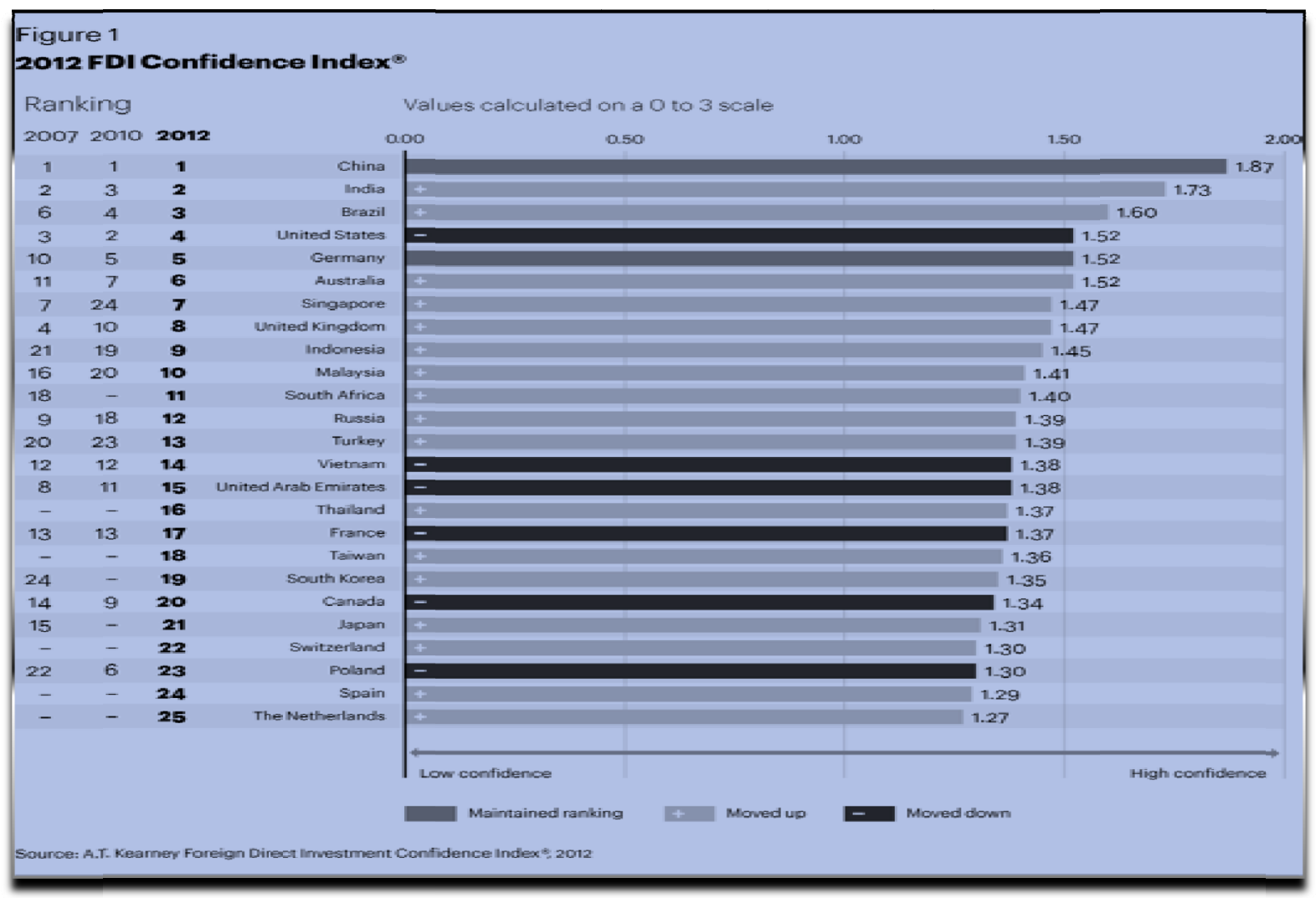

Figure 1. The 2012 A.T. Kearney FDI Confidence Index

\section{5}

- World Trade Organization's General Agreement on Trade in Services, which includes both wholesale and retailing services, came into effect

\section{7}

- FDI in cash and carry (wholesale) with 100 percent rights allowed under the government approval route

\section{6}

- FDI in cash and carry (wholesale) brought under the automatic route

- Up to 51 percent investment in a single-brand retail outlet permitted, subject to Press Note 3 (2006 Series)

\section{1}

- 100 percent FDI in single-brand retail permitted

Figure 2. FDI in India 